\title{
Consumer Evaluation of Cause-Brand Alliance in Cause-Related Advertising: The Role of Brand Familiarity and Personal Relevance
}

\author{
Jaejin Lee (Corresponding author) \\ School of Communication, Florida State University \\ P.O. Box 3062664, Tallahassee, FL 32306, United States \\ Tel: 1-850-644-5034Ｅ-mail: Jaejin.Lee@cci.fsu.edu
}

Hyejoon Rim

School of Journalism and Mass Communication, University of Minnesota 206 Church St. SE., 111 Murphy Hall, Minneapolis, MN55455, United States

Tel: 1-612-624-2491Ｅ-mail: hrim@umn.edu

Received: Dec. 24, $2016 \quad$ Accepted: Jan. 11, $2017 \quad$ Published: May 15, 2017

doi:10.5296/bms.v8i1.11227ＵRL: https://doi.org/10.5296/bms.v8i1.11227

\begin{abstract}
The current study aims to investigate the relative effects of cause-related marketing (CRM) involving cause-brand alliance (CBA) while evaluate the relationship between the cause brand familiarity and personal relevance of the cause. A 2 X 2 (cause brand familiarity: high or low and personal relevance: high or low) experimental study examines the effects on attitudes toward ad, company, and cause-brand alliance (CBA). The overall findings attest to the main effects of cause brand familiarity, personal relevance of the cause, and the interaction effects of the familiarity and relevance. Theoretical and managerial implications, limitations, and future research are discussed.
\end{abstract}

Keywords: Brand familiarity, Personal relevance, Cause-brand alliance, Cause-related marketing 


\section{Introduction}

The use of cause-related marketing has grown significantly over the last several years, and recently, its popularity has increased not only in North America, especially in the United States, but also around the world (Bloom, Hoeffler, Keller, \& Meza, 2006). According to an article in the IEG Sponsorship Report (2007), global expenditures on sponsorship in 2007 reached approximately $\$ 38$ billion while 10 percent of total is sponsoring social causes. Even though the majority of these expenditures are designated to sponsoring sports teams and entertainment, this result shows that companies are still making considerable investments in an attempt to build an affinity with consumers who are interested in social causes (Bloom et al., 2006). Also, this indicate that even though North American spending on sponsorship comprises approximately 40 percent of the total amount, the overall global expenditure on sponsorship in 2007 increased by 12 percent as compared to 2006. This effort on the part of companies to build a good relationship with the consumer (i.e., affinity marketing or cause-related marketing) has become an important strategic move for companies around the world (Bloom et al., 2006).

The concept of cause-related marketing has expanded with consumers' increased need for corporate social responsibility (CSR) and now it is more used synonym as corporate societal marketing. Bloom and his colleagues (2006) define societal marketing as "company initiatives involving the provision of money, resources and/or publicity to socially beneficial cause in a way that seek to create an association in the minds of consumers between the cause and the company or one of its brands" (p. 50). Moreover, Smith and Alcorn (1991) describe cause-related marketing as "a marriage of corporate marketing and social responsibility" (p. 21). Not only has cause-related marketing become commonplace in the business arena, but the benefits of it have also been recognized by consumers, political leaders, non-governmental organizations (NGOs), media and many other institutions (Kerr, Johnston, \& Beatson, 2008). Especially for the consumer, corporate' socially responsible activities remain important despite the recent economic downturn in the United States. Recent studies confirm that consumers are willing to pay more for a product that is tied to a social cause, despite potentially higher prices and the economic recession (Cone Inc., 2010). It study shows that there is an incentive for corporations to consider social-cause related marketing activities.

Many studies have examined the effect of cause-related marketing campaigns from various perspectives, including corporate societal marketing, green marketing, affinity marketing, cause-sponsorship (Barone, Miyazaki, \& Taylor, 2000; Bloom et al. 2006; Sen \& Bhattacharya, 2001). However, since the cause-related marketing became more popular marketing activities for both companies and consumers, marketers need more information to understand the relationship among social causes, consumers, and their company in the process of strategic planning. Thus, in order to achieve a better outcome, marketers and advertisers should know more specific tactics such as the fitness between the brand and the cause or the message framing in the cause-related advertising. At the same time, marketers 
should understand factors in cause-related marketing that can affect to consumers attitudinal and behavioral responses such as brand familiarity, perceived relevance to a issue, or consumers' motivation to participate in cause-related marketing campaigns.

Previous research (Barone, Miyazaki, \& Taylor, 2000; Hoeffler \& Keller 2002; Sen \& Bhattacharya, 2001) shows that consumers tend to have more positive attitude toward the corporate societal marketing including cause-related marketing when the fit between the cause and brand is properly managed. Since, there is many studies have investigated the effectiveness of cause/brand fit. This study evaluates importance of brand familiarity with the personal traits, perceived relevance in this case.

Therefore, the current study aims to investigate the relative effectiveness of cause-related marketing involving cause-brand alliance while evaluate the relationship between the brand familiarity and personal relevance of cause. Specifically, the findings of this study attest to source effects on consequential responses, including the attitude toward the cause-related advertising, the cause-brand alliance, and the company. This study lays the theoretical groundwork about the factors that influence the effects of familiarity and relevance. Also, it provides marketers with useful managerial implications for conducting the corporate societal marketing.

\section{Literature Review}

\subsection{Cause-Related Marketing (CRM)}

Cause-related marketing has been conceptualized as both a tactic and a strategy for fulfilling corporate social responsibilities (Roy \& Graeff, 2003; Till \& Nowak, 2000). Varadarajan and Menon (1988) first defined cause-related marketing as "the process of formulating and implementing marketing activities that are characterized by an offer from the firm to contribute a specified amount to a designated cause when customers engage in revenue-providing exchanges that satisfy organizational and individual objectives" (p. 60). Basically, CRM is a marketing program that strives to improve corporate performance while helping and supporting social causes (Varadarajan \& Menon, 1988). Varadarajan and Menon (1988) identify six marketing objectives to which CRM can be applied to realize companies' ultimate goals; these are increasing sales, enhancing corporate stature, thwarting negative publicity, customer pacification, facilitating market entry, and increasing the level of trade merchandising activity for promoting the brand. In this conception, there are three stakeholders who are involved in CRM programs: the company's consumers, shareholders, and indirect stakeholders who are not directly related to the commercial activity of the firm, including employees, clients, pressure groups, communities, etc. (Brink et al., 2006).

Roy and Graeff (2003) identify two perspectives through which to view cause-related marketing. A narrow view of cause-related marketing is that "it is a tactic designed to simulate short-term sales of a product by making the amount of a contribution to a cause contingent upon unit sales" (p. 164). For instance, Macy's had a partnership with more than 10,000 local and national charities, including the American Heart Association, that raised 
more than $\$ 36$ million in 2009, an increase from the $\$ 32$ million raised with the same campaign in 2008. For the 2009 campaign, Macy's focused on an offer that provided consumers with a savings certificate in exchange for a donation of $\$ 2$ to the AHA's Go Red for Women campaign through activities such as wearing red while shopping (CauseMarketingForum.com, 2011). A broad view of cause-related marketing is that "it should be used as a strategy to link a firm's products with causes or issues that resonate with its target market" (Roy \& Graeff, 2003, p. 164). TOMS's "One for One Movement" is an example of cause-related marketing in a macro perspective. TOMS gives a pair of new shoes to a child in need with every pair a customer purchases. In 2010, the company gave more than one million pairs of shoes to children around the world. In 2011, TOMS started to sell eyewear under its corporate identity and mission of "one for one" (www.toms.com, 2011).

Since American Express conducted the CRM campaign for the Statue of Liberty renovation in 1983, marketers' efforts to reach consumers while linking with social causes have increased consumers' trust and brand loyalty (Grau \& Folse, 2007). Along with the increasing popularity of cause-related marketing practices, both scholars and practitioners have extensively evaluated cause-related marketing strategies and tactics, and analyzed their impact on consumers' perceptual and behavioral relationship with the sponsoring brand and/or the sponsored cause (e.g., Barone, et al., 2000; Hoeffler \& Keller, 2002; Sen \& Bhattacharya, 2001). Moreover, this research has provided empirical evidence that consumers' perceptions of corporate social responsibility not only have a favorable effect on corporate benefits such as loyalty, purchase intention, or emotional attachment, but also on brand equity (Lichtenstein et al., 2004). Thus, cause-related marketing is a versatile tool for achieving corporate and marketing objectives.

Through CRM programs, companies and consumers find "cause-driven partnerships" which means company make a contribution to the community though the partnership with the cause or nonprofits (Grau \& Folse, 2007). In addition, consumers' perceived corporate social responsibility actually increases their nonprofit donations and their willingness to participate in CRM campaigns through consumer-corporate identification (Grau \& Folse, 2007). Consumers tend to perceive the company to be more socially responsible when it conducts CRM campaigns or any other philanthropic activities (Ross, Patterson, \& Stutts, 1992). However, not only companies and consumers benefit from CRM; nonprofit organizations can also benefit from cause-brand partnerships. Nonprofits receive benefits through fundraising and other philanthropic resources that companies or other organizations offer. They can also earn profits through consumers' indirect donations through purchasing the product with CRM campaign (Lichtenstein et al., 2004).

\subsection{Cause-Brand Alliance (CBA)}

Cause-related marketing has often been referred to as a form of marketing or brand alliance (Andreason \& Kotler, 2003). A company creating an alliance with a social cause to make donations is one way to provide evidence of good corporate citizenship, and helps to build trust in the corporation and in the brand (Sen \& Bhattacharya, 2001). This is another way to 
demonstrate corporate social responsibility while partnering a brand with a cause. This kind of partnership between brand and nonprofit organization in support of a certain social cause creates an alliance between the two organizations. Moreover, this cause-brand alliance may result in long-term benefits for the brand, such as strengthening brand positioning and equity, while both the company and nonprofit share the same objective to establish a deeper relationship with consumers. Especially for nonprofits with social causes, such alliances provide benefits in two different forms including revenue from the donations and increased awareness and interest of the cause through the media exposure to the public (Lafferty, Goldsmith, \& Hult, 2004). Lafferty (2009) defines a CBA as:

The long-term partnership between a firm and a cause whereby the firm contributes a specified amount to the cause when consumers purchase designated brands, thus forming a deeper bond with consumers and satisfying the long-term goals of both partners with regard to organizational awareness, image, and market positioning ( $\mathrm{p}$. $360)$.

CRM and CBA are enjoying growing popularity among consumers. According to the study, about 76 percent of consumers have participated in at least one CRM campaign (Lafferty, 2009). Lafferty and colleagues (2004) suggest that the "right" cause will influence the effectiveness of the partnership between a company and a nonprofit organization. They argue, at the same time, that finding the right cause is another important key assignment for marketers when a company wants to make an alliance with a nonprofit organization. Furthermore, marketers should understand the ways in which consumers connect and evaluate both the cause and the brand, and how those consumers' engagements affect their attitude toward the brand and the company (Lafferty et al., 2004). Research has also shown that the facilitating effect of cause-brand alliances (Hoeffler \& Keller, 2002; Simonin \& Ruth, 1998; Lafferty \& Goldsmiths, 2003; Lafferty et al., 2004). Simonin and Ruth (1998) suggest that consumers tend to have positive attitudes toward co-branding between commercial brands and nonprofit organizations. In addition, this kind of alliance could build brand equity by enhancing both the company brand and the nonprofit brand through enhancing the consumers' own self-image, since consumers who are more engaged in CBA or who have tried the product in a CRM campaign are generally perceived to be more altruistic (Hoeffler $\&$ Keller, 2002). The CBA creates a new type of connection with consumers (Lafferty, 2009). Therefore, it is expected to be investigated, and developed more in the marketing arena.

\subsection{The Role of Brand Familiarity}

Brand familiarity is defined as the accumulated knowledge about a brand by the consumer through his or her direct or indirect personal experience with it (Alba \& Hutchinson, 1987; Bettman \& Sujan, 1987; Holden \& Vanhuele, 1999). According to Laroche, Kim, and Zhou (1996), familiarity with a brand is information that the consumer stores that mainly has to do with consumer confidence in the brand rather than objective knowledge about it. In addition, brand familiarity comes from consumers' greater belief in a brand or product based on their own experiences (Hawkins \& Hoch, 1992; Hawkins, Hoch, \& Meyers-Levy, 2001). In other 
words, it is a collection of brand associations that consumers have stored in their memory (Lafferty, 2009).

According to attitude accessibility theory, if the attitude toward the certain object is strong, then it is easier to store the information in the memory, as well as easier to access that information from memory (Fazio, Powell, \& Williams, 1989). Specifically, Lafferty (2009) asserts that consumers tend to have more associations with more familiar brands compared to less familiar or unfamiliar brands, and they tend to retrieve information about familiar brands from their memory more easily than information about less familiar brands. Research shows that increased familiarity with the brand or its products/services results in different effects on consumers' information processing and brand evaluations (Alba \& Hutchinson, 1987). When consumers become familiar with the brand, they perceive the message as one they have knowledge of, and thus they may consider the brand to be more truthful (Lafferty, 2009).

As suggested by attitude theory, it is expected to see that familiar brands produces stronger attitudes due to the extensive associations consumers have with them in their memories, making them more stable and less likely to change as new information is received (Lafferty, 2009; Campbell \& Keller, 2003; Simonin \& Ruth, 1998). Therefore, it is believed that the knowledge a consumer has about a company or a nonprofit organization not only influence his or her attitude towards the firm's products or services but also help form positive feelings towards the company (Brown and Cody, 1991).

H1: Exposure to an cause-related advertising message with the cause-brand alliance involving high (versus low) cause brand familiarity will lead to more favorable (a) attitude toward the cause-related ad, (b) attitude toward the company, and (c) attitude toward the cause-brand alliance.

\subsection{Effect of Personal Traits: Altruistic Motives, Perceived Importance, and Relevance of Cause}

Research on CBA is marked by a particular interest in the effect of personal traits. In the selection of a potential partner in a CBA, such things as how consumers are motivated, how important the cause is perceived to be, and how relevant the cause is by consumer, should have a differential effect on attitudes and behavioral intentions (Lafferty, 2009; Grau \& Folse, 2007; Hoeffler \& Keller, 2002; Bizer \& Krosnick, 2001; Smith \& Alcorn, 1991; Krosnick, 1989).

First, consumer motivation to engage in certain social causes might be an important factor in CRM and CBA. Even though, from a marketer's perspective, the objective of CRM is to enhance a consumer's favorable attitude toward the brand and company and increase the demand to purchase their products or services engaged with cause-brand alliance, if consumers are motivated by altruistic motives (Smith \& Alcorn, 1991). They describe altruistic motivation as a "result from either social norms or learned personal commitment to the specific recipient" (p. 25). Altruistic motivation, derived from social responsibility, is directed by personal norms and may affect an individual's behavior, as well as consumer 
attitudes (Smith \& Alcorn, 1991). In general, individuals involved with a cause should be more likely to participate in related campaigns, in comparison with those who are less involved (Grau \& Folse, 2007). Consumers may think a certain social cause is more important than others based on personal beliefs, thus feeling that this cause needs more urgent support from society, even though it has no personal relevance to them (Lafferty, 2009).

Just as brand familiarity can affect the accessibility of knowledge in memory, and produce stronger attitudes toward both brands and causes, several researchers have found that a positive relationship between the perceived importance, or relevance, of an object and the accessibility and strength of attitudes concerning it (Bizer \& Krosnick, 2001; Krosnick, 1989). In addition, given the influence of both familiarity and attitude strength, Lafferty (2009) argues that there is a differential effect on the CBA when a less important, or more important, cause is paired with a familiar brand, than when paired with an unfamiliar one. In the study, researchers found the importance of cause a moderating effect. For example, when a less important cause is linked with both familiar and less familiar brands, it is expected that the effect of the partnership is greater on attitude toward the unfamiliar brand, while attitude toward the familiar brand is significantly more positive overall.

Although the personal relevance of a cause has not been specifically addressed in CBA and CRM research, a few studies have indirectly examined its effectiveness (Grau \& Folse, 2007; Lafferty, 2009; Hoeffler \& Keller, 2002). Theoretically, any association related to a cause can affect brand equity. However, in general, judgments or feelings may be more likely to transfer than other association related to a cause (Grau \& Folse, 2007). Furthermore, the relevance of a cause may vary by consumer. According to Grau and Folse (2007), one of the possible ways to improve personal relevance is to emphasize the local aspects of a cause. Also, in general, relevance may be enhanced if the CRM with CBA component is believed to have a personal influence on the consumer.

H2: Consumers' perceived relevance of the cause in the cause-brand alliance will lead to more favorable (a) attitude toward the cause-related ad, (b) attitude toward the company, and (c) attitude toward the cause-brand alliance.

\subsection{Interaction Effects}

No literature has explicitly compared brand familiarity with the personal relevance to the cause, though few scholars have asserted the relative importance of brand familiarity with the individual traits (Lafferty, 2009; Nan \& Heo, 2007; Hoeffler \& Keller, 2002; Zaichkowsky, 1985). When the importance of the cause increases in a cause-brand alliance, attitude toward the brand and company for the familiar brand is more favorable than unfamiliar one (Lafferty, 2009). Also, consumers with high brand consciousness is highly sensitive to the user image conveyed by the brand while low brand-conscious consumers are now concerned about the user image and less sensitive to ambiguity in brand-user image (Nan \& Heo, 2007). In addition to, individuals with a high-involvement to a cause should be more favorable to the 
CRM activities with CBA and more likely to participate in campaigns than those who are less involved (Grau \& Folse, 2007), and thus individuals with personal relevance of cause should have more enhanced associations with the nonprofit to the brand (Hoeffler \& Keller, 2002).

Given the influence of both brand familiarity and personal traits to the cause as indicants of attitude strength, and as moderators of the consumers' attitude, it is expected to see the different effect of the CBA when a less relevant or more relevant cause is paired with a familiar brand than an unfamiliar one. Therefore, the following hypotheses are suggested:

H3: The effect of the level of the personal relevance in the cause (high versus low) on (a) attitude toward the cause-related ad, (b) attitude toward the company, and (c) attitude toward the cause-brand alliance will be more pronounced when nonprofit brand is unfamiliar (versus familiar).

\section{Method}

\subsection{Pretest}

Prior to conducting the experiment, a pre-test was employed to select the cause to manipulate the level of familiarity. Since, this study is more focused on the effectiveness of cause brand familiarity, researchers chose to use the fictitious pharmaceutical brand, Acof. Pharmaceutical brand is generally perceived as a health related company, it would be appropriate to choose a health-related nonprofit organization as a partner in the cause-brand alliance. Based on "The Cone Nonprofit Power Brand 100" report, six cause brands in the same sector (i.e., health) were chosen: three from top-rank and three from low-ranked cause brand. In order to avoid potential confounding variable, familiarity and attitudes toward cause brand were assessed.

Twenty-eight participants asked to evaluate their familiarity for the following brands: American Cancer Society (ranked no. 1 power brand in the health sector), St. Jude Children's Research Hospital (ranked no. 5 in the health sector), and Susan G. Komen Breast Cancer Foundation (ranked no. 8 in the health sector). The other set of low-familiarity brands group include Muscular Dystrophy Association (ranked no. 16 in the health sector, no. 46 across the sector), Mental Health America (ranked no. 23 in the health sector, no. 97 across the sector), and United Cerebral Palsy Association (ranked no. 24 in the health sector, no. 98 across the sector).

Familiarity was measured by asking a seven-point semantic differential scale with three items: familiar/unfamiliar, recognize/did not recognize, had heard of/had not heard of (Lafferty, 2009). The attitudes toward cause brand was measured by Mackenzie and Lutz's (1989) scale, which is composed of three bipolar items: good/bad, favorable/unfavorable, and pleasant/unpleasant. Each item was measure on 7-point bipolar scale. To this end, St. Jude Children's Research Hospital was selected as high-familiarity cause brand $(M=6.4, S D=$ 1.7), whereas United Cerebral Palsy Association was selected as low-familiarity $(M=2.7)$ brand.

\subsection{Research Design and Stimulus Development}


For this study, a 2 (cause brand familiarity: high or low) X 2 (perceived relevance of the cause: high or low) between-subjects randomized experimental study was conducted to test the proposed hypotheses. The main experimental study used advertisements as stimulus materials. Between the two independent variables, a cause brand with high versus low brand familiarity was manipulated in an advertising message with the exact wording of the CRM message which is adopted from Nan and Heo's study (2007). Before showing the cause-related advertising, brief description about the fictitious commercial brand, Acof, and its socially responsible activities was presented to help respondents understand the brand. In the cause-related advertising, he message was as follows: "Acof is a sponsor of the St. Jude Children's Research Hospital (as a high-familiarity brand, United Cerebral Palsy Association as a low-familiarity brand) to prevent child and adolescent mental health problems. For every product sold, we donate 25 cents to this worthy cause." The other independent variable, perceived relevance of the cause, was gauged with the brief explanation about cause prior to the brand familiarity manipulation about a fictitious CRM campaign in order to be split at the sample median. Each experimental stimulus featured an image of the pharmaceutical product on a sky blue background. A headline (i.e., "Cure the World") and fictitious brand description in a smaller font (i.e., "With high-quality and innovative product, Acof is committed to improving the quality of human life.") appeared in the middle of the advertisement. Company Web site information was placed at the bottom of the advertisement. All these features of the ad were the same across the experimental conditions.

\subsection{Participants and Data Collection}

An experiment was conducted to test the hypotheses through the online. A total of 322 undergraduate students recruited from introductory and advanced communication classes in a large Southeastern university in exchange for extra credits. Participants were randomly assigned to one of the two experimental conditions. Upon consenting to take part in the study, participants were asked to rate the personal relevance to the provided cause and view the corresponding advertisement with the manipulated brand familiarity. The participants then filled out the questionnaire. Males and females comprised 31.5 percent and 68.5 percent of the sample, respectively. The average age of participants was 20 years $(\mathrm{SD}=1.20)$.

\subsection{Measures}

Brand Familiarity. Based on Simonin and Ruth (1998) measurement, participants were asked to rate their overall impression of the nonprofit brand (Cronbach's $\alpha=.95$ ) on three-item, seven-point bipolar adjective scale. The scale was anchored by familiar/unfamiliar, recognize/did not recognize, heard of/had not heard of.

Relevance of the Cause. Participants were indicated their personal relevance to the cause. Personal relevance was measure by Zaichkowsky's (1994) scale, which is composed of ten items: importance, relevance, personal significance, value, necessity, interest, excitement, appeal, fascination, and involvement. Each item was measure on a 7-point bipolar scale.

Attitude toward the Cause-Related Ad. Subjects were asked to rate their overall impression of 
the advertisement (Cronbach's $\alpha=.95$ ) on a three-item, seven-point bipolar adjective scale based on MacKenzie and Lutz's (1989) measurement for attitudes. The scale was anchored by good/bad, favorable/unfavorable, and pleasant/unpleasant.

Attitude toward the Company. Participants' attitude toward the company (Cronbach's $\alpha=.96$ ) was assessed via a three-item, seven-point bipolar scale anchored by very likely/very unlikely, probable/improbable, and possible/impossible (MacKenzie and Lutz, 1989).

Attitude toward the Cause-Brand Alliance. Based on Simonin and Ruth's (1998) measurement, attitude toward the alliance (Cronbach's $\alpha=.97$ ) was measured with a three-item, seven-point bipolar adjective scale which was adopted from. For attitude toward the alliance, the anchors were good/bad, favorable/unfavorable, and pleasant/unpleasant.

Self-Altruism. Based on Rushton, Chrisjohn, and Fekken (1981) measurement, self-altruism (Cronbach's $\alpha=.91$ ) was measured with an eighteen-item Likert scale ranging from 1 (extremely unlikely) to 7 (extremely likely). The specific statements were: "I have assisted someone experiencing car trouble," "I have given someone directions," "I have given money to someone who needed it," "I have done volunteer work for charity," "I find it sometimes amusing to upset the dignity of teachers, judges, and 'cultured' people," "I have donated blood," "I have helped carry another person's belongings," "I have delayed an elevator and held the door open for another," "I have allowed someone to go ahead of me in a line," "I have given another a ride in my car," "I have pointed out a clerk's error in undercharging me for an item," "I have let someone borrow an item of some value to me," "I have helped another with a homework assignment when my knowledge was greater than his or hers," "I have voluntarily looked after another's plants, pets, house, or children without being paid for it," "I have offered my seat in a crowded room or on a train or bus to someone who was standing," "I have helped another to move his or her possessions to another room, apartment, or house," and "I have retrieved an item dropped by another for him or her."

\section{Results}

\subsection{Manipulation Checks}

A series of independent samples t-test were conducted to verify whether the manipulation of nonprofit organization familiarity in cause-brand alliance significantly altered participants' attitudes toward the company and alliance. The analysis revealed a significant effect of nonprofit organization's brand familiarity manipulations $(t=-16.37, \mathrm{p}<.001)$. The mean score for the advertisement featuring cause-brand alliance with high nonprofit brand familiarity $(\mathrm{M}=5.56)$ was significantly higher than that for the advertisement with low nonprofit brand familiarity $(M=2.72)$. Also, the participant's personal relevance to the social cause that is supported by the nonprofit organization was split at the median to create two subgroups (i.e., low- and high-relevance). The numbers and mean scores of low- and high-relevance are respectively: $\mathrm{n}=182(\mathrm{M}=4.00, \mathrm{SD}=1.01)$ and $\mathrm{n}=140(\mathrm{M}=6.29, \mathrm{SD}$ $=.52, \mathrm{t}=-25.54, \mathrm{p}<.001)$. 


\subsection{Confounding Checks}

To see whether the manipulation of cause brand familiarity resulted in different perception toward the cause, an ANOVA (analysis of variance) was performed, where the independent variable was cause brand familiarity and the dependent variable was the potential confounding variable which is a consumers' altruistic motivation to engage in a certain social cause. Univariate test results indicated no significant effect of the nonprofit organization brand on consumers' altruistic motivation $(\mathrm{p}>.80)$. Both groups indicated a relatively low personal altruistic motives to the social cause $\left(\mathrm{M}_{\text {high_familiarity }}=2.86 ; \mathrm{M}_{\text {low_familiarity }}=2.85\right)$.

\subsection{Hypothesis Testing}

Hypotheses 1 suggested that exposure to an advertising message with a CRM component involving nonprofit brand familiarity would be more likely to lead to (a) positive attitudes toward the cause-related advertisement, (b) positive attitudes toward the company; and (c) positive attitude toward the cause-brand alliance. And, hypotheses 2 predicted that consumers' perceived relevance of the cause will lead to (a) positive attitudes toward the cause-related advertisement, (b) positive attitudes toward the company; and (c) positive attitude toward the cause-brand alliance. Hypothesis 3 further posited the interaction effect between two main effect that suggests the impact of nonprofit brand familiarity on (a) attitude toward the cause-related ad, (b) attitude toward the company, and (c) attitude toward the cause-brand alliance would be more pronounced for individuals high (versus low) in perceived relevance of the cause.

Hypothesis 1, 2, and 3 were tested through a series of two-way ANOVA where the independent variables were nonprofit brand familiarity (high versus low) and cause relevance (high versus low), and the dependent variables were attitude toward the cause-related ad, attitude toward the company, and attitude toward the cause-brand alliance. The results for hypothesis 1 show that the nonprofit brand familiarity had significant effects on attitude toward the cause-brand alliance, $\mathrm{F}(1,318)=5.64, \mathrm{p}<.05$. There were no significant differences in the effects of nonprofit brand familiarity on attitude toward the cause-related ad, $F(1,318)=$ $1.16, \mathrm{p}>.1$, and attitude toward the company $\mathrm{F}(1,318)=.55, \mathrm{p}>.1$. Thus, H1(c) was supported but H1 (a) and H1 (b) were not supported.

The results for hypothesis 2 shows that consumers' perceived relevance of the cause had significant effects on attitude toward the cause-related ad, $\mathrm{F}(1,318)=80.03, \mathrm{p}<.001$, attitude toward the company, $\mathrm{F}(1,318)=131.90, \mathrm{p}<.001$, and attitude toward the cause-brand alliance, $\mathrm{F}(1,318)=109.98, \mathrm{p}<.001$ (see Table 1). Thus, $\mathrm{H} 2$ (a) through $\mathrm{H} 2$ (c) were supported.

Table 1. A Summary of Hypothesis Testing

\begin{tabular}{llll}
\hline Dependent variable & $\begin{array}{l}\text { Familiarity } \\
\text { main effect }\end{array}$ & $\begin{array}{l}\text { Relevance } \\
\text { main effect }\end{array}$ & $\begin{array}{l}\text { Familiarity } \\
\text { X Relevance }\end{array}$ \\
\hline Attitude toward the cause-related ad & $F=1.16$ & $F=80.03^{* * *}$ & $F=.37$
\end{tabular}


Attitude toward the company 2017, Vol. 8, No. 1

Attitude toward the cause-brand alliance $F=5.64^{*}$

$\begin{array}{lll}F=.37 & F=131.90^{* * *} & F=7.53^{* *} \\ F=5.64^{*} & F=109.98^{* * *} & F=4.43^{*}\end{array}$

Note: ${ }^{*} p<.05,{ }^{* *} p<.01,{ }^{* * *} p<.001$.

Regarding the interaction effects predicted in $\mathrm{H} 3$, the results show that nonprofit brand familiarity and consumers' perceived relevance of the cause significantly impact attitude toward the company, $F(1,318)=7.53, p<.01$. Interaction effects were also significant for attitudes toward alliance, $F(1,318)=4.43, p<.05$, but not significant for attitudes toward the cause-related ad, $F(1,318)=.37, p>.1$. The results reveal that the effects of nonprofit brand familiarity on individuals' attitudes toward the company and its alliance with the social cause depended primarily on consumers' perceived relevance of the cause in the alliance. Therefore, H3 (b) and H3 (c) were supported; but, H3 (a) was not supported (See Figure 1 and Figure 2).

Figure 1. The Interaction between Brand Familiarity and Cause Relevance

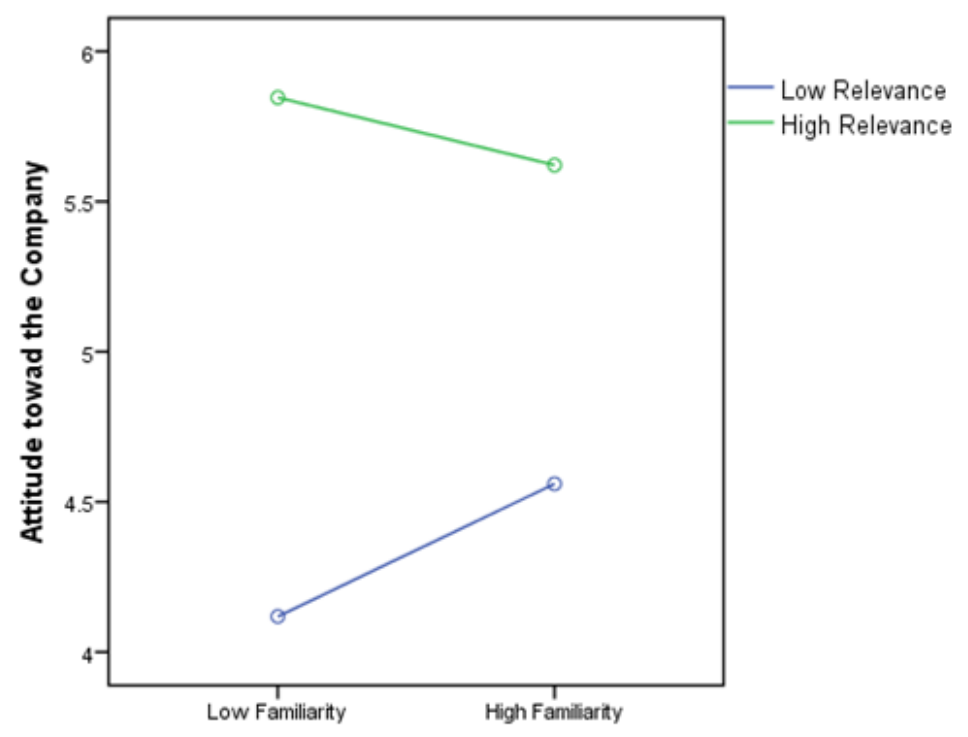

(Dependent Variable: Attitude toward the Company)

Figure 2. The Interaction between Brand Familiarity and Cause Relevance 


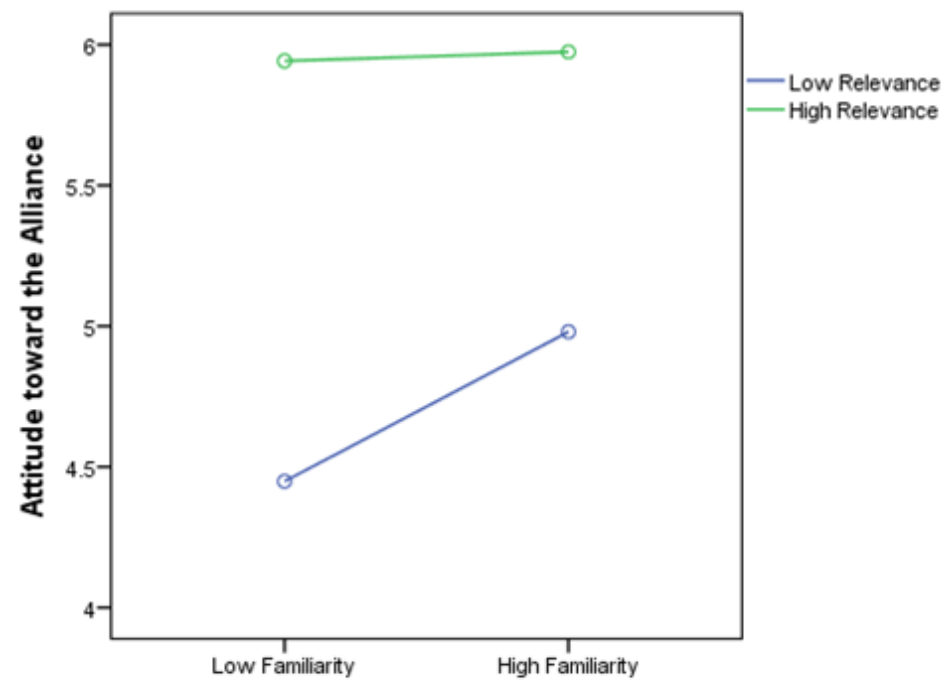

(Dependent Variable: Attitude toward the Cause-Brand Alliance)

As shown in Table 2, the results of the main effects reveal that the mean difference between high- and low- perceived relevance of the cause within a high brand familiarity condition reached statistical significance for attitude toward the company $\left(M_{\text {high_relevance }}=5.62\right.$; $\left.M_{\text {low_relevance }}=4.56\right)$. There were also significant differences between attitudes toward the cause-brand alliance $\left(M_{\text {high_relevance }}=5.97 ; M_{\text {low_relevance }}=4.98\right)$. Furthermore, mean difference between high- and low- perceived relevance of the cause within a low brand familiarity condition reached statistical significance for attitude toward the company $\left(M_{\text {high_relevance }}=5.85\right.$; $\left.M_{\text {low_relevance }}=4.12\right)$ and attitude toward the alliance $\left(M_{\text {high_relevance }}=5.94 ; M_{\text {low_relevance }}=4.45\right)$.

Table 2. Simple Main Effects of Means (Mean Difference)

$$
\text { High Familiarity Low Familiarity }
$$

Dependent variable

High vs. Low High vs. Low

Relevance Relevance

Attitude toward the company

Attitude toward the cause-brand alliance
5.62 vs. $4.56(1.06)^{*}$

5.97 vs. $4.98(.99)^{*}$
5.85 vs. $4.12(1.73)^{*}$

5.94 vs. $4.45(1.49)^{*}$

Note: ${ }^{*} p<.01$.

In conclusion, when participants have higher or lower familiarity of nonprofit brand and higher perceived relevance of the cause, they perceive more favorable attitude toward the company, and respond to the cause-brand alliance more favorably. The effect of personal 
relevance is (even) greater when a cause brand has low familiarity than high familiarity. Thus, the results confirm the interaction effects in H3. Means and standard deviations for all dependent variables are summarized in Table 3.

Table 3. Means and Standard Deviations of all Dependent Variables

\begin{tabular}{|c|c|c|c|c|}
\hline & \multicolumn{2}{|c|}{ High Familiarity } & \multicolumn{2}{|c|}{ Low Familiarity } \\
\hline Dependent variable & $\begin{array}{c}\text { High } \\
\text { Relevance }\end{array}$ & $\begin{array}{c}\text { Low } \\
\text { Relevance }\end{array}$ & $\begin{array}{c}\text { High } \\
\text { Relevance }\end{array}$ & $\begin{array}{c}\text { Low } \\
\text { Relevance }\end{array}$ \\
\hline Attitude toward the cause-related ad & $\begin{array}{c}5.42 \\
(1.21)\end{array}$ & $\begin{array}{c}4.32 \\
(1.05)\end{array}$ & $\begin{array}{c}5.36 \\
(1.16)\end{array}$ & $\begin{array}{c}4.11 \\
(1.13)\end{array}$ \\
\hline Attitude toward the company & $\begin{array}{l}5.62 \\
(1.13)\end{array}$ & $\begin{array}{l}4.56 \\
(.96)\end{array}$ & $\begin{array}{l}5.85 \\
(.97)\end{array}$ & $\begin{array}{c}4.12 \\
(1.09)\end{array}$ \\
\hline Attitude toward the cause-brand alliance & $\begin{array}{c}5.97 \\
(1.08)\end{array}$ & $\begin{array}{c}4.98 \\
(1.03)\end{array}$ & $\begin{array}{l}5.94 \\
(.89)\end{array}$ & $\begin{array}{c}4.45 \\
(1.08)\end{array}$ \\
\hline
\end{tabular}

\section{Discussion}

\subsection{Theoretical and Managerial Implications}

All cause brands cannot be aware of and resonate to consumers when the company initiate the cause-related marketing campaign. In other words, certain cause brand is better suited for specific brand than others. This study provide useful insights into the potential benefits and liabilities of using a cause brand which supports certain kind socially desirable cause in connection with commercial brand to promote cause-related marketing campaigns. Building on these insights, the present study indicates that cause-related marketing yield more favorable attitudinal outcomes when consumer are more familiar with the cause brand. Moreover, interestingly, a positive impact of cause-related marketing occurs primarily on consumers' attitude toward the company and the cause-brand alliance rather than their attitudes toward the cause-related adverting.

First, this study focused on the role of cause brand familiarity in improving the overall effectiveness of cause-related marketing with cause-brand alliance. It reveals that more familiar and well-known cause brand generates greater attitude toward the cause-brand alliance. Nevertheless, this study did not find that attitude toward the cause-related ad and company were influenced by the cause brand familiarity. It shows that consumers do not respond to cause-related advertisement even the company support the familiar cause brand. As suggested by attitude theory, consumers who are familiar with cause brand tend to have stronger 
attitudes due to the extensive associations consumers already have with the cause brand. As a result, in this research, the cause-related advertisement with familiar cause brand may increase favorable attitude toward the cause brand (generally, nonprofit organization) but did not lead to the favorable attitude toward the advertisement and the company with the cause brand they do not have any association before.

Furthermore, this study assessed the role of personal relevance of cause in eliciting more positive responses to communication strategies including attitude toward the cause-related ad, attitude toward the company, and attitude toward the cause-brand alliance. This finding indicates that when consumers involve more in the specific social cause that company is supporting, they perceive the cause-related advertisement as more favorable. Also, when consumer consider the social cause more importantly, they have more positive attitude toward the company which initiate the cause-related marketing campaign and also they understand the alliance between commercial brand and nonprofit brand more positively. As result, it is believed if the social cause in the cause-related marketing have a personal influence on the consumer, then this social cause may enhance the overall campaigns' positive result. Therefore, choosing a right social cause is important when the company decide to initiate the cause-related marketing campaign. As consumers change their attitude and perceptions toward the company which concerns the same social cause as they do (Hoeffler \& Keller, 2002), now marketers and advertisers should more concern about understanding their target consumers social conciseness and apply the outcome to the marketing activities when they want to connect more with consumers, increase brand equity, and building a strong brand. According to Grau and Folse (2007), one of the possible ways to improve personal relevance is to emphasize the local aspects of a cause. Therefore, for the local brands, the result suggest that it should be more focused on the community level cause-local brand alliance. At the same time, for national or global brands, this study outcome propose that it should entail more grassroots corporate societal marketing activity at the local level.

Finally, the interaction effects of personal relevance of the cause and cause brand familiarity for cause-related marketing suggest that the effect of personal relevance of the cause on cause-brand alliance evaluation is greater when a cause brand is not familiar with the consumers. Specifically, the impact of personal relevance was greater for the cause-related with cause-brand alliance when company is partnering with less familiar cause brand. Also, people perceive that an alliance more favorable when they feel they are more related to the cause even though company is partnering with less familiar nonprofit brand. However, these effects did not affect attitudes toward the adverting. Our findings suggest the importance of personal relevance of the cause on cause-brand alliance evaluation, especially when a cause brand is not familiar to the consumers.

As discussed previously, increased familiarity of cause brand and personal relevance should enhance the transfer of associations from the nonprofit to the company and the alliance at the same time. With this in mind, this results of the study are expected to provide managerial guidance with regard to cause-related marketing with cause-brand alliance. Based on the 
results, this present study provides a basic understanding of how to utilize a cause-brand alliance for more successful cause-related marketing. Not only the high degree familiarity and awareness is important but the cause brand with the relevance cause is also a crucial cue to the successful cause-related marketing campaign. To achieve a company's purpose, marketer's need to cooperate more with the nonprofit organizations to increase the cause brand visibility to the public and also enhance the familiarity with consumers in the targeted market. Furthermore, marketers are highly encouraged to focus more on the social issues which is highly concerned by the public when they decide to initiate societal marketing.

\subsection{Limitation and Suggestions for Future Studies}

Several limitations of this study need to be acknowledged. One major limitation of the experiment is the use of a fictitious brand, which was expected to strengthen the internal validity of the study design, but, it threats the external validity. In reality, lots of well-known companies try to do a cause-related marketing campaign with well-known nonprofit organizations (cause brand) to establish more brand equity and expanding their market share. Therefore, respondents would not be exposed to a cause-related marketing program involving an unfamiliar cause brand before and it may affect to the result. For the next research, it will be more interesting to test both nonprofit brands and commercial brand and see how consumers' familiarity toward the each brand affect to their attitudinal and behavioral response.

Another limitation is that this study employed a convenience college student sample. For the future study, the sample should be more various than the college student. In addition to, this study only manipulate brand familiarity. But, since many of previous research has focused on the cause/brand fit, it would be more interesting to see the outcome if the study consider both brand familiarity and cause/brand fit with the personal relevance. Therefore, it could give more insight to the CRM programs while considering both company oriented factors including cause/brand fit and brand familiarity and consumer oriented factors including personal relevance, perceived important, and altruistic motivations.

\section{References}

Aaker, D. A., \& Keller, K. L. (1990). Consumer evaluations of brand extensions. Journal of Marketing, 54(1), 27-41. Retrieved from http://www.jstor.org/stable/125217

Alba, J. W., \& Hutchinson, J. W. (1987). Dimensions of consumer expertise. Journal of Consumer Research, 13(4), 411-435. http://dx.doi.org/10.1086/209080

Andreasen, A. R., \& Kotler, P. (2003). Strategic marketing for nonprofit organizations. Upper Saddle River, NJ: Prentice Hall.

Becker-Olsen, K. L., Cudmore, B. A \& Hill, R. P. (2006). The impact of perceived corporate social responsibility on customer behavior. Journal of Business Research, 59(1), 46-53. http://dx.doi.org/10.1016/j.jbusres.2005.01.001

Bettman, J. R., \& Sujan, M. (1987). Effects of framing on evaluation of comparable and 
non-comparable alternatives by expert and novice consumers. Journal of Consumer Research, 14, 141-154. http://dx.doi.org/10.1016/j.jbusres.2005.01.001

Bhattacharya, C. B. \& Sen, S. (2003). Consumer-company identification: A framework for understanding consumers' relationships with companies. Journal of Marketing, 67, 76-77. Retrieved from http://www.jstor.org/stable/30040524

Bizer, G. Y., \& Krosnick, J. A. (2001). Exploring the structure of strength-related attitude features: The relation between attitude importance and attitude accessibility. Journal of Personality and Social Psychology, 81, 566-586. doi:10.1037//0022-3514.81.4.566

Bloom, P. N., Hoeffler, S., Keller, K., \& Meza, C. E. B. (2006). How social-cause marketing affects consumer perceptions. MIT Sloan Management Review, 47(2), 49-55.

Brink, D. V. D., Odekerken-Schröder, G., \& Pauwels, P. (2006). The effect of strategic and tactical cause-related marketing on consumers' brand loyalty. Journal of Consumer Marketing, 23(1), 15 - 25. http://dx.doi.org/10.1108/07363760610641127

Brown, M. J., \& Cody, M. J. (1991). Effects of a prosocial television soap opera in promoting women's status. Human Communication Research, 18(1), 114-142. doi:10.1111/j.1468-2958.1991.tb00531.x

Carroll, A. B. (1979). A three-dimensional conceptual model of corporate social performance. Academy of Management Review, 4, 497-505. http://dx.doi.org/10.5465/AMR.1979.4498296

Cone Inc. (2007), Cone cause evolution and environmental survey report. Retrieved from http://www.coneinc.com/files/2007ConeSurveyReport.pdf

Cone Inc. (2010), More than three-quarters of Americans say a nonprofit-corporate partnership makes a cause stand out. Retrieved from http://www.coneinc.com/research/archive.php

Davis, K. (1973). The case for and against business assumption of social responsibility. Academy of Management Journal, 312-322. http://dx.doi.org/10.2307/255331

Demetriou, M., Papasolomou, L. \& Vrontis, D. (2010). Cause-related marketing: Building the corporate image while supporting worthwhile causes. Journal of Brand Management, 17(4), 266-278. http://dx.doi.org/10.1057/bm.2009.9

Drumwright, M. (1996). Company advertising with a social dimension: the role of noneconomic criteria. Journal of Marketing, 60, 71-87. http://dx.doi.org/10.2307/1251902

Fazio, R. H., Powell, M. C., \& Williams, C. J. (1989). The role of attitude accessibility in the attitude-behavior process. Journal of Consumer Research, 16(3), 280-288. Available: http://www.jstor.org/stable/2489509

File, K. M., \& Prince, R. A. (1998). Cause related marketing and corporate philanthropy in the privately held enterprise. Journal of Business Ethics, 17, 1529-1539. http://dx.doi.org/ 
10.1023/A:1005869418526

Grau, S. L., \& Folse, J. A. G. (2007). Cause-related marketing (CRM): The influence of donation proximity and message-framing cues on the less-involved consumer. Journal of Advertising, 36(4), 19-33. http://dx.doi.org/10.1086/209214

Gray, R. (2000). Developing a tight fit is crucial to CRM. Marketing, 4, 37-38. Retrieved from http://bi.galegroup.com.proxy.lib.fsu.edu/essentials/article/GALE\%7CA62216336?u=tall857 61

Hawkins, S. A., and Hoch, S. J. (1992). Low-involvement learning: Memory without Evaluation. Journal of Consumer Research, 19(2), 212-225. Available: http://www.jstor.org/stable/2489329

Hoeffler, S. \& Keller, K. L. (2002). Building brand equity through corporate societal marketing. Journal of Public Policy \& Marketing, 21(1), 78-89. Available: http://www.jstor.org/stable/30000710

Hogg, M. A. (1996). Social identity, Self-categorization, and the small group. In J. Davis \& E. Witte (Eds.), Understanding group behavior, Volume 2: Small group processes and interpersonal relations (pp. 227-254). Hillsdale, NJ: Lawrence Erlbaum Associates.

Hogg, M. A., Terry, D. J., \& White, K. M. (1995). A tale of two theories: A critical comparison of identity theory with social identity theory. Social Psychology Quarterly, 58, 255-269. Available: http://www.jstor.org/stable/2787127

Holden, S. J. S., \& Vanhuele, M. (1999). Know the name, forget the exposure: Brand familiarity versus memory of exposure context. Psychology \& Marketing, 16, 479-496. Retrieved from www.4b10eaee694973dddf5e388ef62e2cc5578a.pdf

IEG Sponsorship Report (2007). Sponsorship Spending On Causes To Total \$1.55 Billion This Year, Retrieved from https://www.sponsorship.com

Kotler, P., \& Lee, N. (2005). Corporate Social Responsibility: Doing the Most Good for Your Company and Your Cause. Hoboken, NJ: Wiley.

Krosnick, J. A. (1988). Attitude importance and attitude change. Journal of Experimental Social Psychology, 24, 20-255. http:dx.doi.org/10.1016/0022-1031(88)90038-8

Lafferty, B. A. (2009). Selecting the right cause partners for the right reasons: The role of importance and fit in cause-brand alliances. Psychology \& Marketing, 26(4), 359-382. http://dx.doi.org/ 10.1002/mar.20277

Lafferty, B. A., \& Goldsmith, R. E. (1999). Corporate credibility's role in Consumers' attitudes and purchase intentions when a high versus a low credibility endorsers is used in the Ad. Journal of Business Research, 44(2), 109-116. http://dx.doi.org/10.1016/S0148-2963(98)00002-2 
Lafferty, B. A., Goldsmith, R. E., \& Hult, G. T. M. (2004). The impact of the alliance of the partners: A look at cause-brand alliances. Psychology \& Marketing, 21(7), 509-531.

Laroche, M., Kim, C., \& Zhou, L. (1996). Brand familiarity and confidence as determinants of purchase intention: An empirical test in a multiple brand context. Journal of Business Research, 37(2), 115-120. http://dx.doi.org/10.1016/0148-2963(96)00056-2

Lichtenstein, D. R., Drumwright, M. E., \& Braig, B. M. (2004). The effect of corporate social responsibility on customer donations to corporate-supported nonprofits. Journal of Marketing, 68(October), 16-32. Available: http://www.jstor.org/stable/30162013

MacKenzie, S. B., \& Lutz, R. J. (1989). An empirical examination of the structural antecedents of attitude toward the ad in an advertising pretesting context. Journal of Marketing, 53(2), 48-65. Retrieved from http://www.jstor.org/stable/1251413

Mele, D. (2008). Corporate social responsibility theories. In A. Crane., A. McWilliams, D. Matten, J. Moon, and D. S. Siegel (Ed.), The Oxford handbook of corporate social responsibility (pp. 47-82). Oxford: Oxford University Press.

Menon, S., \& Kahn, B. E. (2003). Corporate sponsorships of philanthropic activities: When do they impact perception of sponsor brand. Journal of Consumer Psychology, 13(3), 316-327. http://dx/doi.org/10.1207/S15327663JCP1303_12

Mohr, L. A., Webb, D. J. \& Harris, K. E. (2001) Do consumers expect companies to be socially responsible? The impact of corporate social responsibility on buying behavior. Journal of Consumer Affairs, 35(1), 25-73. http://dx.doi.org/ 10.1111/j.1745-6606.2001.tb00102.x

Murray, K. B., \& Vogel, C. M. (1997). Using a hierarchy of effects approach to gauge the effectiveness of CSR to generate goodwill towards the firm: Financial versus nonfinancial impacts. Journal of Business Research, 38(2), 141-159. http://dx.doi.org/10.1016/S0148-2963(96)00061-6

Nan, X., \& Heo, K. (2007). Consumer response to corporate social responsibility (CSR) initiatives: Examining the role of brand-cause fit in cause-related marketing," Journal of Advertising, 36(2), 63-74. $\quad$ Retrieved from http://bi.galegroup.com.proxy.lib.fsu.edu/essentials/article/GALE\%7CA165431165?u=tall85 761

Sen, S., \& Bhattacharya, C. B. (2001). Does doing good always lead to doing better? Consumer reactions to corporate social responsibility. Journal of Marketing Research, 38 (2), 225-243. http://dx.doi.org/10.2753/JOA0091-3367360204

Simonin, B. L., \& Ruth, J. L. (1998). Is a company known by the company it keeps? Assessing the spillover effects of brand alliances on consumer brand attitudes. Journal of Marketing Research, 35(1), 30-42. Retrieved from http://www.jstor.org/stable/3151928 


\section{Macrothink}

Smith, S. M., \& Alcorn, D. S. (1991). Cause marketing: A new direction in the marketing of corporate responsibility. Journal of Consumer Marketing, 8(3), 19-28. http://dx.doi.org/10.1108/07363769110035054

TOMS.com (2010). One For One Movement. Retrieved from http://www.toms.com/our-movement

Varadarajan, P. R., \& Menon, A. (1988). Cause-related marketing: A coalignment of marketing strategy and corporate philanthropy. Journal of Marketing, 52(3), 58-74. http://dx.doi.org/10.2307/1251450

Webb, D. J., \& Mohr, L. A. (1998). A typology of consumer response to cause-related marketing: From skeptics to socially concerned. Journal of Public Policy and Marketing, 17(2), 226-238. Retrieved from http://www.jstor.org/stable/30000773

Wood, D. J. (1991). Corporate social performance revisited. Academy of Management Review, 16, 691-718. Retrieved from http://www.jstor.org/stable/258977

\section{Copyright Disclaimer}

Copyright for this article is retained by the author(s), with first publication rights granted to the journal.

This is an open-access article distributed under the terms and conditions of the Creative Commons Attribution license (http://creativecommons.org/licenses/by/3.0/). 